\title{
Meðferð og afdrif sjúklinga með mjaðmarbrot
}

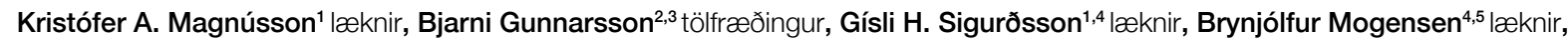
Yngvi Ólafsson ${ }^{6}$, læknir Sigurbergur Kárason ${ }^{1,4} \mid æ k n i r$
\end{abstract}

\section{ÁGRIP}

Inngangur: Mjaðmarbrot eru algeng meðal aldraðra, oft með alvarlegum afleiðingum og hárri dánartíđni. Markmið pessarar rannsóknar var að kanna meðferð og afdrif sjúklinga sem hlutu mjaðmarbrot og voru meðhöndlaðir á Landspítala.

Efniviður og aðferðir: Afturskyggn rannsókn á öllum sjúklingum $\geq 60$ ára sem gengust undir skurðaðgerð á Landspítala árið 2011 vegna mjaðmarbrots.

Niðurstöður: Rannsóknarhópurinn samanstóð af 255 sjúklingum (meðalaldur $82 \pm 8$ ár, konur $65 \%$ ). Bið eftir aðgerð frá komu á spítalann var að meðaltali $22 \pm 14$ klukkustundir. Meðallegutími sjúklinga á spítalanum sem voru á hjúkrunarheimili fyrir brot var $4 \pm 2$ dagar en meðallegutími peirra sem bjuggu á eigin heimili $14 \pm 10$ dagar $(p<0,001)$. Fyrir mjaðmarbrotið bjuggu $68 \%$ sjúklinganna á eigin heimili en $54 \%$ við lok eftirfylgdar $(p<0,001)$. Dánarhlutfall ári eftir brot var $27 \%$ sem er áttfalt hærra en meðaltal einstaklinga yfir 60 ára á Íslandi. Aðhvarfsgreining sýndi að aldur, tími frá áverka að komu á bráđamóttöku, ASA-flokkun og mjaðmarbrot hjá vistmanni á hjúkrunarheimili tengdust marktækt áhættu á andláti einu ári eftir aðgerð.

Ályktun: Samsetning hópsins sem mjađmarbrotnar hér á landi er ápekk pví sem gerist erlendis. Meðalbiðtími eftir aðgerð var tæpur sólarhringur, sem er innan marka erlendra gæðastaðla, en priðjungur sjúklinga beið lengur. Umönnunarúrræđi utan sjúkrahúss virtust helst ráđa hversu löng sjúkrahúsdvölin varð. Marktækt færri gátu búið á eigin heimili eftir brot en fyrir. Dánarhlutfall mjað̋marbrotinna var margfalt hærra en í sama aldurspýđi á Íslandi og í efri mörkum miðað við erlendar rannsóknir. Mjaðmarbrot hafa pví alvarlegar afleiðingar fyrir einstaklinginn og eru krefjandi fyrir samfélagið.
Fyrirspurnir: Sigurbergur Kárason skarason@landspitali.is

${ }^{1}$ Svæfinga- og gjörgæsludeild Landspítala, ${ }^{2}$ verkfræðiog raunvísindadeild Háskóla Íslands, 3íslenskri erfðagreiningu, ${ }^{4}$ æknadeild Háskóla Íslands, ${ }^{5}$ rannsóknastofu Landspítala og $\mathrm{HI}$ í bráđafræðum, ${ }^{6}$ bæklunarskurðdeild Landspítala. Evrópu, nánar tiltekið á Norðurlöndunum. Pessi munur milli pjóða er álitinn tengjast hárri tíðni beinpynningar og hugsanlega algengi D-vítamínskorts á norðlægum slóðum. ${ }^{9}$

Allir sjúklingar sem mjaðmarbrotna fara í aðgerð nema peir séu pað langt leiddir að andlát sé yfirvofandi við komu á sjúkrahús. ${ }^{10}$ Hjá eldra fólki eru lærleggshálsbrot oftast meðhöndluð með innri festingu ef pau eru ótilfærð en í tilfærðum brotum er annaðhvort notuð innri festing eða settur gerviliður. ${ }^{11}$ Stöðug lærhnútubrot eru oftast meðhöndluð með renninagla og plötu en óstöðug með mergnagla. ${ }^{12}$
Mjaðmarbrot eru algengir áverkar meðal aldraðra og
hafa oft alvarlegar afleiðingar fyrir einstaklinginn og valda umtalsverðum kostnaði fyrir samfélagið. ${ }^{1} \mathrm{Al}-$ gengi slíkra brota eykst með aldri sem skýrist af aldMeðalaldur peirra sem mjaðmarbrotna er á bilinu 80hluta peirra sem mjaðmarbrotna, eða um $70 \% .^{5-7}$ Beinsem gæti skýrt að miklum hluta hvers vegna konu mjaðmarbrotna frekar en karlar.

Nýgengi mjaðmarbrota er pó misjafnt eftir heimshlutum og er pað almennt hærra pví lengra sem farið er
Umdeilt er hvort bið eftir aðgerð auki dánartíðni en í nýlegri safngreiningu (metaanlysis) var sýnt fram á tengsl snemmbúinnar aðgerðar og lægri dánartíðni. Einnig var minni hætta á lungnabólgu og legusárum. Раð er pó misjafnt eftir rannsóknum hvort snemmbúin aðgerð sé flokkuð innan 24, 48 eða 72 klukkustunda frá innlögn. ${ }^{13}$ Kanadísk rannsókn sýndi að styttri bið eftir aðgerð lækkaði dánartíð ni bæði við 30 daga og eitt ár eftir aðgerð. Útkoman varð verri eftir pví sem biðin var lengri. ${ }^{14}$ Í rannsóknum par sem biðtími hefur ekki haft marktæk áhrif á dánartíðni hefur styttri bið að jafnaði tengst styttri legutíma. ${ }^{15-17}$ Í nýlegum leiðbeiningum frá Bretlandi er mælt með að sjúklingar fari í aðgerð innan eins til tveggja sólarhringa frá innlögn. ${ }^{10}$

Sjúklingar sem gangast undir aðgerð vegna mjaðmarbrots fá annaðhvort mænudeyfingu eða eru svæfðir. Í nýlegum rannsóknum hefur ekki fundist munur á dánartíðni milli mænudeyfingar og svæfingar ${ }^{18,19}$ en aðgerðar- og legutími er styttri ef mænudeyfing er notuð. ${ }^{18}$ Einnig hefur verið sýnt fram á minni líkur á blóðsegamyndun í djúpum bláæðum og færri blóðgjafir við mænudeyfingu. ${ }^{19}$

Meðallegutími eftir mjaðmarbrot er misjafn eftir löndum en hann er á bilinu 9-12 dagar í Bretlandi og Danmörku ${ }^{5,20}$ en einungis 5-6 dagar í Bandaríkjunum. ${ }^{21}$ Skipulag heilbrigðiskerfis hefur að sjálfsögðu mikil 
áhrif á pennan pátt, til dæmis aðgengi að heimahjúkrun, sjúkrahótelum, hjúkrunarheimilum og endurhæfingu eftir aðgerð.

Dánarhlutfall sjúklinga sem hafa mjaðmarbrotnað er töluvert hærri en í hinu almenna pýði á sama aldri. ${ }^{7}$ Prjátíu daga dánartíðni eftir innlögn eða aðgerð er um 8-10\% $\%^{4,6}$ og eins árs dánartíðni milli 16-30\%.,22-24 Dánartíðnin er hærri hjá körlum en konum, ${ }^{3,4,6}$ um 30\% á móti $20 \%$ einu ári eftir brot. ${ }^{3}$

Tilgangur pessarar rannsóknar var að gefa yfirlit um meðferð og afdrif sjúklinga sem mjaðmarbrotna og gangast undir aðgerð á Landspítala með sérstakri áherslu á bið eftir aðgerð, búsetu eftir útskrift af sjúkrahúsi og dánartíðni einu ári eftir mjaðmarbrot.

\section{Efniviður og aðferðir}

Framkvæmd var afturskyggn rannsókn á sjúklingum, 60 ára og eldri, sem mjaðmarbrotnuðu og gengust undir aðgerð á Landspítala frá 1. janúar til 31. desember 2011. Lengd eftirfylgdar var 18-30 mánuðir, eða að meðaltali tvö ár. Sjúklingarnir voru valdir eftir sjúkdómsgreiningunum S72.0 (lærleggshálsbrot) og S72.1 (lærhnútubrot). Aldursbil og sjúkdómsgreiningar voru valdin í samræmi við pær rannsóknir sem helst var miðað við en hvorttveggja er misjafnt eftir rannsóknum og gagnagrunnum.

Tilskilin leyfi voru fengin frá Siðanefnd Landspítala, Persónuvernd og framkvæmdastjóra lækninga á Landspítala.

Gögn voru unnin úr sjúkraskrám og tölvukerfum Landspítala, sjúkraskrárkerfinu Sögu og aðgerðarkerfinu Orbit í pví augnamiði að fá almennt yfirlit yfir feril og afdrif sjúklinga eftir útskrift, en upplýsinga um andlát var aflað úr Pjóðskrá.

Breytur sem voru skráđar voru kyn, aldur, ASA-flokkun (áhættuflokkun sjúklinga samkvæmt American Society of Anesthesiologists, ${ }^{25}$ ) tími frá broti að komu á bráðamóttöku, biðtími eftir aðgerð, hvort aðgerð var framkvæmd fyrir eða eftir 24 klukkustundir eftir greiningu, tegund brots, hvort aðgerð var framkvæmd í svæfingu eða deyfingu, lengd aðgerðar, tími á vöknun, legutími á bæklunardeild, búseta fyrir og eftir brot og dánarhlutfall einu ári eftir brot og í lok eftirfylgdar.

Upplýsingar um tíma frá broti að komu á sjúkrahús voru fengnar úr sjúkraskrá og flokkað í innan við 6 klukkustundir frá áverka, milli 6 og 12 klukkustundir, milli 12 og 24 klukkustundir og lengur en 24 klukkustundir.

Tveir sjúklingar biðu óvenju lengi eftir aðgerð, annar í 15 daga og hinn í 5 vikur og voru peir ekki teknir með í tölfræðigreiningu. Í fyrra tilfellinu greindist brotið ekki strax en í pví seinna var ekki hægt að taka sjúklinginn til aðgerðar vegna legusárs.

Öll gögn voru skráð í Microsoft Excel. Tölfræðiforritið R (útgáfa 3.2.3, The R Foundation for Statistical Computing) var notad til greiningar og úrvinnslu gagna.

Niðurstöður eru birtar sem meðaltal, miðgildi, staðalfrávik og bil. Tölfræðileg marktækni milli hópa var könnuð með kí-kvaðrat prófi, t-prófi og log-rank test, miðað var við p<0,05 fyrir tölfræðilega marktækni.

Framkvæmd var Cox-aðhvarfsgreining par sem dánarhlutfall eftir eitt ár var háður páttur. Óháðir pættir voru aldur, kyn, ASAflokkun, tími frá broti að komu á bráðamóttöku, bið eftir aðgerð, bústaður fyrir brot og hvort gefin var mænudeyfing eða svæfing

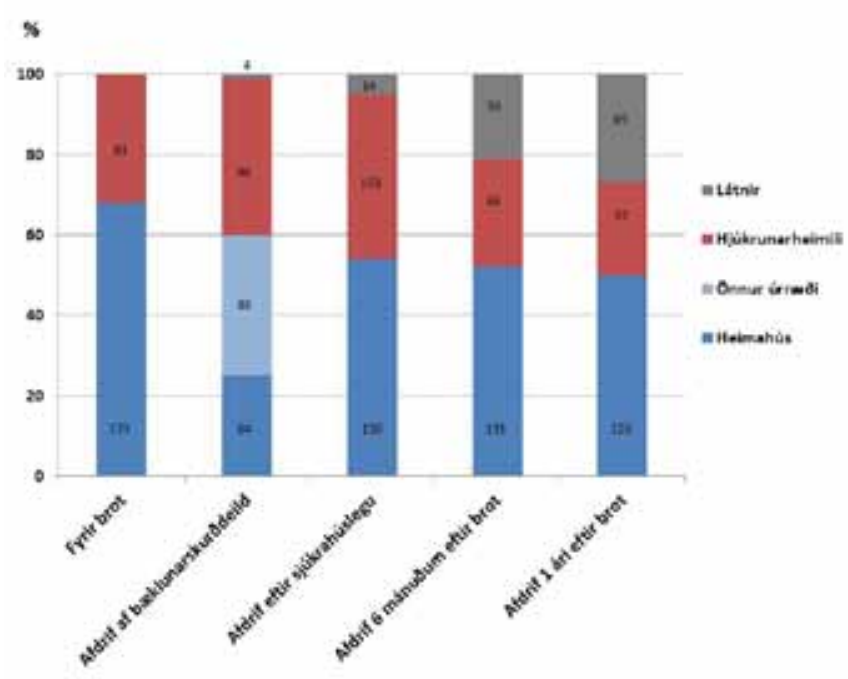

Mynd 1. Búsetustaður og dánarhlutfall sjúklinga fyrir og eftir mjaðmarbrot. Fjöldi sjúklinga bakvið hlutfallið i hverjum hóp kemur fram í súlunum. Önnur úrræði við útskrift af bæklunarskurðdeild: Önnur legudeild innan Landspitala, öldrunardeild, annað sjúkrahús og sjúkrahótel. Af peim 69 sem voru látnir einu ári eftir brot bjuggu 40 (49\% dánarhlutfall) á hjúkrunarheimili fyrir brot og 29 (17\% dánarhlutfall) $i$ heimahúsi. Upplýsingar um búsetu vantaði fyrir nokkra sjúklinga og er heildarfjöldi pví ekki 255 í öllum súlunum.

í aðgerðinni. Niðurstöður eru birtar sem p-gildi með 95\% efri og neðri öryggisbil (Confidence Interval, CI) á áhættuhlutfalli.

Upplýsingar um lifun sjúklinga voru fengnar úr Pjóðskrá 30. júní 2013. Lifunargreining (Survival-analysis) var notuð til að reikna lifun sjúklinga í dögum og birt í Kaplan-Meier grafi.

Dánartíðni peirra sem höfðu mjaðmarbrotnað var borin saman við dánartíðni í almennu pýði $\geq 60$ ára í pjóðfélaginu árið 2011, skipt í 10 ára aldursbil samkvæmt upplýsingum á heimasíðu Hagstofu (hagstofa.is).

\section{Niðurstöður}

Alls fóru 255 einstaklingar í aðgerð vegna mjaðmarbrots á rannsóknartímabilinu. Af pessum 255 einstaklingum voru 166 (65\%) konur og 89 (35\%) karlar. Meðalaldur var 82 ár ( \pm 8 ár; spönn 60107). Meðalaldur karla var 82 ár ( $\pm 7,7$ ár; spönn 61-101) og kvenna 83 ár ( \pm 8,1 ár; spönn 60-107). Ekki var marktækur munur á aldri kynjanna $(\mathrm{p}=0,207)$.

Fleiri hlutu brot á lærleggshálsi (62\%) en lærhnútu (38\%), og var pessi munur marktækur meðal kvenna $(p=0,001)$ en ekki karla $(\mathrm{p}=0,46)$. Раð var ekki marktækur munur á dánarhlutfalli eftir tegund brota $(\mathrm{p}=0,455)$.

Frá áverka að komu á bráðamóttöku liðu innan við 6 klukkustundir hjá 158 (62\%) sjúklingum, 6-12 klukkustundir hjá 42 (17\%), 12-24 klukkustundir hjá 24 ( $9 \%$ ) og meira en 24 klukkustundir hjá 22 (9\%). Dánarhlutfall var hærra í hópnum par sem meira en 6 klukkustundir liðu frá áverka að komu á bráðamóttöku ( $\mathrm{p}=0,008)$.

Meðalbiðtími eftir aðgerð var 21,8 tímar ( \pm 13,9, spönn 3-77). Rúmlega einn priðji hluti sjúklinga, eða 91 (36\%), purfti að bíða lengur en 24 tíma eftir aðgerð. Í 47 tilfellum (52\% af peim sem biðu >24 tíma) var bið vegna anna á spítala eða engin ástæða tekin fram en 24 ( $26 \%$ af peim sem biðu >24 tíma) voru á blóðpynn- 


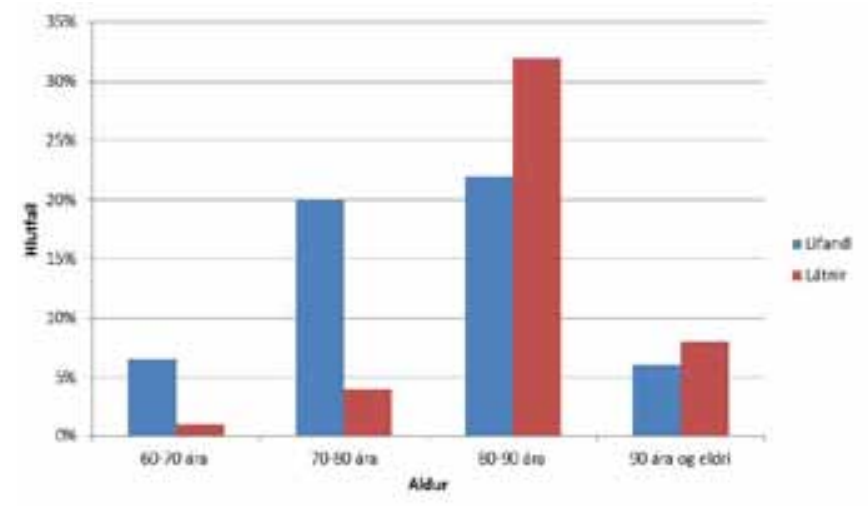

Mynd 2. Dánarhlutfall sjúklinga samkvæmt aldursbilum eftir mjaðmarbrot í lok eftirfylgdar sem var að meðaltali tvö ár.

ingu við innlögn sem purfti að leiðrétta fyrir aðgerð og 17 (19\% af peim sem biðu >24 tíma) gátu ekki farið strax í aðgerð vegna annarra heilsufarsvandamála. Í premur tilfellum greindist brotið ekki strax við innlögn. Dánarhlutfall einu ári eftir aðgerð hjá peim sem fóru í aðgerð innan 24 tíma var 26\% en 31\% hjá peim sem biðu lengur, pessi munur reyndist ekki marktækur $(\mathrm{p}=0,445)$. Meirihluti sjúklinga voru mænudeyfðir, eða 215 (85\%), en 39 (15\%) voru svæfðir. Pað var ekki marktækur munur á lifun milli mænudeyfingar og svæfingar $(\mathrm{p}=0,723)$.

Meðallengd aðgerðar var 50,1 mínúta ( \pm 19,3, spönn 12-174). Meðaltími á vöknun var 4,6 tímar ( $\pm 2,4$, spönn 2-23).

Af peim sjúklingum sem hlutu lærleggshálsbrot fengu 104 (66\%) gervilið og 53 (34\%) innri festingu. Af peim sem hlutu lærhnútubrot fóru 89 (92\%) í innri festingu með renninagla og plötu en $6(6 \%)$ fengu mergnagla. Einn fékk gervilið.

Meðallegutími á bæklunarskurðdeild var 10,9 ( \pm 9,9, spönn 1-51) dagar en miðgildi var lægra, eða 8 dagar. Meðallegutími sjúklinga sem bjuggu á eigin heimili fyrir brot var 14,3 dagar $( \pm$

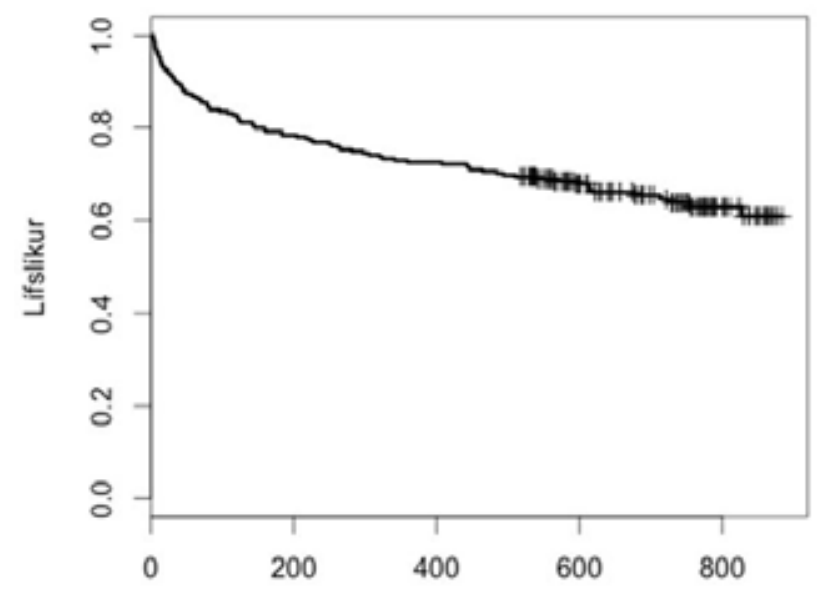

Dagar frá ađgero

Mynd 3. Á pessu Kaplan-Meier-grafi sést lifun sjúklinga eftir mjaðmarbrot í dögum eftir aðgerð allt tímabil eftirfylgdar sem var frá 18-30 mánuðir.

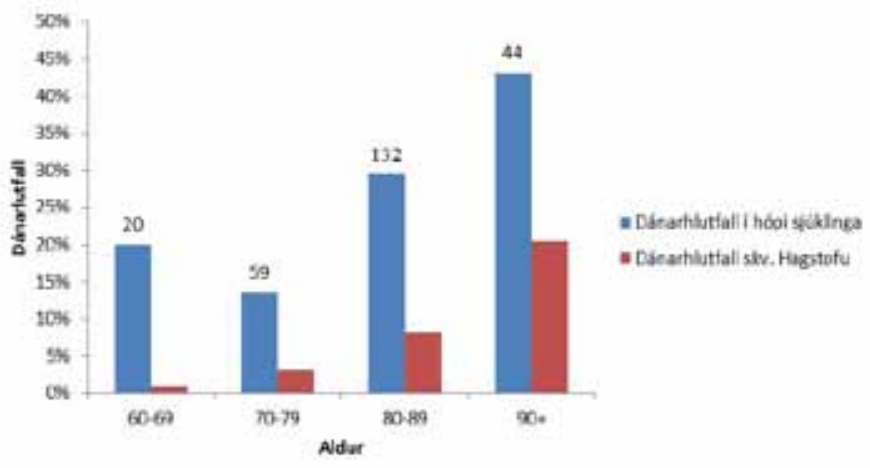

Mynd 4. Eins árs dánarhlutfall sjúklinga eftir mjaðmarbrot borið saman við dánartíðni i almenna pýđinu á sama aldri i 10 ára aldursbilum árið 2011. Fjöldi sjúklinga í hverjum aldurshópi er gefinn upp fyrir ofan súlur.

10,3, spönn 1-51) en 3,8 ( $\pm 2,2$, spönn 1-14) hjá peim sem bjuggu á hjúkrunarheimili $(\mathrm{p}=0,001)$. Einungis $64(25 \%)$ sjúklingar voru útskrifaðir beint heim af bæklunarskurðdeild, 98 (39\%) útskrifuðust á hjúkrunarheimili, 37 (15\%) á annað sjúkrahús, 25 (10\%) á öldrunardeild, 12 (5\%) á aðra legudeild Landspítalans og 14 (6\%) á sjúkrahótel (mynd 1).

Fyrir brot bjuggu 173 (68\%) á eigin heimili og 81 (32\%) á hjúkrunarheimili. 136 (54\%) sjúklingar voru útskrifaðir heim að lokum, eða $79 \%$ af peim sem bjuggu heima fyrir brot. 103 (41\%) fóru á hjúkrunarheimili en 14 (6\%) létust í legunni á bæklunardeild. Pað bjuggu marktækt færri á eigin heimili eftir að hafa mjaðmarbrotnað en fyrir (p=0,001) (mynd 2). 27 (11\%) sjúklingar purftu að leggjast aftur inn á sjúkrahús vegna mjaðmarbrotsins.

Enginn sjúklingur lést í aðgerð, 22 (9\%) sjúklingar létust innan 30 daga frá aðgerð, 40 (16\%) innan priggja mánaða, 52 (20\%) innan 6 mánaða, 68 (27\%) innan árs frá aðgerð og 89 (34\%) voru dánir í lok rannsóknartímabils sem varaði frá 18 til 30 mánaða (mynd 2 og 3). Ekki var marktækur munur á dánarhlutfalli karla (30\%) og kvenna (26\%) einu ári frá aðgerð $(\mathrm{p}=0,159)$.

Dánartíðni meðal peirra sem hlotið höfðu mjaðmarbrot var talsvert hærri pegar borið var saman við almennt pýði $\geq 60$ ára á 10 ára aldursbilum (mynd 4). Mestur var munurinn á aldursbilinu 60-70 ára.

Niðurstaða Cox-aðhvarfsgreiningar sýndi að aldur ( $\mathrm{p}=0,004 ; \mathrm{CI}$ 1,02-1,1), ASA-flokkun ( $\mathrm{p}=0,003 ; \mathrm{CI}$ 1.2-2.6), tími frá broti að komu á bráðamóttöku ( $\mathrm{p}=0,01 ; \mathrm{CI} 1,06-1,56)$ og bústaður fyrir brot $(\mathrm{p}=0,0001$; CI 1,66-5,35) voru áhættupættir fyrir andláti einu ári eftir aðgerð. Hins vegar reyndust kyn, tegund brots, biðtími eftir aðgerð, hvort beitt var svæfingu eða deyfingu í aðgerðinni ekki hafa áhrif á áhættu fyrir andláti í pessari rannsókn.

\section{Umræða}

Pessi rannsókn sýnir að dánartíðni peirra sem mjaðmarbrotna er verulega aukin miðað við dánartíðni annars fólks á sama aldri. Hún sýnir jafnframt að sjálfsbjargargeta peirra sem lifa af er verulega skert par sem mun færri geta búið á eigin heimili og fleiri purfa vistun á hjúkrunarheimilum.

Sjúklingar með mjaðmarbrot eru oft og tíðum með marga undirliggjandi sjúkdóma og góð heildræn meðferð krefst sam- 
Tafla I. Meðalaldur og kynjahlutfall ásamt dánartíðni við 30 daga og eitt ár, borið saman við erlendar rannsóknir.

\begin{tabular}{|c|c|c|c|c|c|c|c|}
\hline Höfundar & Land & Tímabil & Fjöldi sjúklinga & Meðalaldur & Kynjahlutfall & $\begin{array}{l}\text { Dánarhlutfall } \\
\text { við } 30 \text { daga }\end{array}$ & $\begin{array}{l}\text { Dánarhlutfall } \\
\text { við eitt ár }\end{array}$ \\
\hline Kristófer A. Magnússon et al. & Ísland & 2011 & 255 & 82 ár & $65 \%$ konur & $9 \%$ & $27 \%$ \\
\hline Andreas P. Diamantopoulos et al. ${ }^{3}$ & Noregur & 2004-2005 & 942 & 81 ár & $72 \%$ konur & & $21 \%$ \\
\hline Socialstyrelsen ${ }^{29}$ & Svípjóð & $2010-2012$ & 40.300 & & $67 \%$ konur & $10 \%$ & $26 \%$ \\
\hline Lund et al. ${ }^{24}$ & Danmörk & $2005-2007$ & 6143 & 83 ár & $74 \%$ konur & & $30 \%$ \\
\hline Simran Mundi et al. ${ }^{22}$ & Bandaríkin & $2000-2013$ & 13.379 & & & & $21 \%$ \\
\hline
\end{tabular}

vinnu bráðalækna, bæklunarskurðlækna, svæfingarlækna, öldrunarlækna, endurhæfingarlækna, sjúkrapjálfara, hjúkrunarfólks og iðjupjálfa, auk áætlana um hvað skuli síðan taka við eftir að sjúkrahúsdvöl lýkur.

Hlutfall kvenna sem hlaut mjaðmarbrot var talsvert hærra en karla, eða $65 \%$ á móti $35 \%$, sem er pekkt frá fyrri rannsóknum. ${ }^{5,7,26,27}$ Petta hlutfall kvenna er pó heldur lægra ef borið er saman við eldri íslenska rannsókn par sem hlutfallið var $72 \%{ }^{28}$ og rannsóknir frá Noregi og Danmörku par sem hlutfallið var $71 \%^{7}$ og $72 \%{ }^{5}$, en sambærilegt við tölur frá Svípjóð, eða $67 \%{ }^{29}$

Meðalaldur sjúklingahópsins var 82 ár sem er sambærilegt við erlendar rannsóknir. ${ }^{3-6}$ Ekki var marktækur munur á meðalaldri kynjanna pó svo að konur fái að jafnaði beinpynningu fyrr. Fæstir sjúklingar falla í yngsta aldurhópinn en flestir eru á bilinu 80-89 ára.

Fleiri hlutu lærleggshálsbrot en lærhnútubrot og var pessi munur marktækur hjá konum $(p=0,001)$ en ekki körlum. Samskonar mun hefur áđur verið lýst bæði á Íslandii ${ }^{28}$ og í Noregi. ${ }^{30}$

Pví lengur sem leið frá áverka að komu á bráðamóttöku jókst dánartíðni marktækt ( $\mathrm{p}=0,008)$. Ekki fundust sambærilegar upplýsingar í öðrum rannsóknum. Hugsanleg skýring gæti verið að hluti peirra sem brotna eiga erfitt með að gera vart við sig vegna verkja og skertrar hreyfifærni eða að almennt ástand peirra sé lakara, sem gerir peim erfiðara að kalla eftir hjálp. Peir geta pví legið bjargarlausir um hríð, sem eykur hættu á alvarlegum fylgikvillum. Fjölgun neyðarhnappa gæti hugsanlega bætt hér úr.

Meðalbiðtími eftir aðgerð frá innlögn á bráðamóttöku var 22 tímar. Petta er innan marka breskra leiðbeininga sem mæla með pví að sjúklingar fari í aðgerð innan eins til tveggja sólarhringa frá innlögn. ${ }^{10} \mathrm{Um}$ einn priðji sjúklinganna beið pó lengur en 24 tíma eftir aðgerð sem bendir til að bæta megi skipulag við meðferð pessara sjúklinga og að skortur sé á aðgengi að skurðstofu til að koma að slíkum bráðaaðgerðum. Einu ári eftir aðgerð var dánarhlutfall hærra í hópnum sem beið lengur en 24 klukkustundir eftir aðgerð (31\% á móti $26 \%$ ), pó ekki marktækt, en heilsufarsvandamál (19\%) eða leiðrétting á blóðpynningu (26\%) olli töfinni í tæplega helmingi pessa hóps og pví mætti ætla að hann væri veikari. Hér gæti einnig skipt máli að leiðrétta blóðpynninguna og önnur heilsufarsvandamál með sem bestum hætti til að tryggja möguleika á að komast í aðgerð sem fyrst, en erlendar rannsóknir hafa sýnt að styttri bið lækkar dánartíðni, bæði við 30 daga og einu ári eftir aðgerð. ${ }^{14}$

Í pessari rannsókn voru flestir sjúklingar mænudeyfðir (85\%) fyrir aðgerð en peir sem ekki var hægt að mænudeyfa voru svæfðir. Рað var enginn munur á dánarhlutfalli milli mænudeyfingar og svæfingar, sem er sama niðurstaða og í nýlegum erlendum rannsóknum. Mænudeyfing virðist pó hafa vissa kosti fram yfir svæfingu í mjaðmarbrotum, með lægri tíðni fylgikvilla og styttri aðgerðar- og legutíma. . $^{18,19,31}$

Meðallegutími á bæklunarskurðdeild var 11 dagar sem er sambærilegt við 9-12 daga í Bretlandi og Danmörku ${ }^{5,20}$ en töluvert lengri en í Bandaríkjunum ${ }^{21}$ par sem hann var 5-6 dagar. Marktækur munur var á legutíma sjúklinga sem búa á eigin heimili og hjúkrunarheimili fyrir brot, eða 14 og fjórir dagar hvor um sig $(\mathrm{p}=0,001)$. Hópurinn sem kemur frá eigin heimili er væntanlega að jafnaði frískari en liggur að meðaltali 10 dögum lengur á sjúkrahúsinu. Líklegt er að hægt væri að stytta legutíma hjá pessum sjúklingahópi með góðu aðgengi að sjúkrahóteli og heimahjúkrun, auk endurhæfingar. Seinni hópurinn er væntanlega viðkvæmari en hefur greiðan aðgang að umönnun á hjúkrunarheimili pegar ástand peirra er orðið stöðugt og ekki lengur talin pörf á vistun á bráđadeild sjúkrahúss. Hins vegar gæti hugsast að prýstingur sé á að útskrifa pessa sjúklinga sem fyrst par sem umönnunarúrræði eru til staðar fyrir pennan hóp en dánartíðni var marktækt hærri hjá peim sem bjuggu á hjúkrunarheimili fyrir brot $(\mathrm{p}=0,0001)$.

Раð bjuggu marktækt færri á eigin heimili eftir brot heldur en fyrir brot ( $p=0,001)$. Af peim 173 (68\% af heildarhópnum) sem bjuggu á eigin heimili fyrir brot útskrifuðust 136, eða $79 \%$ peirra, aftur heim til sín að lokum. •að er pví töluverður hluti sjúklinga sem ekki nær fyrri færni eftir mjaðmarbrot. Рað gátu einungis $37 \%$ sjúklinga útskrifast aftur á fyrra heimili beint eftir spítalaleguna en í einni breskri rannsókn og annarri danskri voru pessi hlutföll $57 \%{ }^{32}$ og $64 \% .^{5}$ Skipulag heilbrigðiskerfis hefur að sjálfsögðu áhrif hér á en hugsanlega mætti hækka hlutfall peirra sem útskrifast beint heim með aukinni heimapjónustu.

Tíðni endurinnlagna var $11 \%$. Erlendis er petta hlutfall um $12 \%$ en par er miðað við endurinnlögn innan 30 daga. ${ }^{33}$ Í pessari rannsókn voru öll tilfelli endurinnlagna höfð með sem var hægt að rekja til fylgikvilla mjaðmarbrotsins, óháo tíma.

Dánarhlutfall við 30 daga eftir aðgerð var 9\% sem er sambærilegt við erlendar rannsóknir., ${ }^{4,6}$ Eins árs dánarhlutfallið var $27 \%$ sem er sambærilegt við Svípjóð árin 2010-2012 par sem 30 daga dánartíðni eftir mjaðmarbrot var 10\% og eins árs dánartíðni $26 \%$ hjá hópi 50 ára og eldri með fyrsta mjaðmarbrot. ${ }^{29}$ Dánarhlutfallið var einnig sambærilegt við danska rannsókn par sem eins árs dánartíðnin var 30\%. ${ }^{24}$ Petta er pó nokkru hærra en í nokkrum nýlegum erlendum rannsóknum par sem dánartíðnin var 16-21\% (tafla I). 3,26,27 Pað var ekki marktækur munur á dánartíðni milli kvenna og karla eins og sést í erlendum rannsóknum par sem dánartíðni er hærri hjá körlum. ${ }^{3,4,6}$ Eins og fram kom að ofan virðist vera 
ójafnvægi í lengd sjúkrahúsdvalar milli sjúklingahópa sem koma að heiman og frá hjúkrunarheimilum og gæti pað hugsanlega haft áhrif á dánartíðni hér á landi ári eftir mjaðmarbrot.

Dánarhlutfall var mjög aukið hjá peim sem mjaðmarbrotnuðu ef borið var saman við almenna pýðið á sama aldri, en að meðaltali var dánartíðnin áttfalt hærri hjá peim sem höfðu mjaðmarbrotnað en var breytileg eftir aldursbilum (mynd 4). Petta er sambærilegt við tölur frá Noregi en par sást, eins og í pessari rannsókn, að munurinn á dánarhlutfalli var meiri í yngri aldursflokkunum. ${ }^{7}$

Aðhvarfsgreining sýndi að hærri aldur, lengri tími frá áverka að komu á bráðamóttöku, hærri ASA-flokkun og ef vistmaður á hjúkrunarheimili brotnaði, jók marktækt áhættuna á andláti innan árs frá aðgerð.

Helsti styrkur pessarar rannsóknar er að rannsóknartímabilið nær yfir heilt ár og úrtakið pví nokkuð stórt. Enn fremur var sjúklingum fylgt lengur eftir í pessari rannsókn en mörgum erlendum rannsóknum. Upplýsingar úr sjúkraskrá og pjóðskrá virtust áreiðanlegar og lítið um eyður.

Hvað varðar veikleika rannsóknarinnar má nefna að hún er afturskyggn og pví háð peirri skráningu sem framkvæmd var á hverjum tíma en mat á sjúkdómsbyrði, færni og hrumleika við innlögn var ábótavant. Jafnframt vantar upplýsingar um marga sértæka pætti á ýmsum stigum í ferli sjúklinganna, meðal annars orsök andláts hjá peim sem létust eftir að hafa hlotið mjaðmarbrot á tímabilinu. Rannsóknin var fyrst og fremst hönnuð til að gefa almennt yfirlit um meðferð og afdrif pessa sjúklingahóps, vekja athygli á honum og hvetja til frekari rannsókna.

\section{Ályktanir}

Sjúklingahópurinn er svipaður hér á landi og erlendis en hlutfall kvenna aðeins lægra. Pví lengra sem leið frá áverka að komu á bráðamóttöku jókst marktækt hætta á andláti innan árs frá aðgerð. Meðalbiðtími eftir aðgerð var tæpur sólarhringur, sem er innan marka erlendra gæðastaðla, en priðjungur sjúklinga beið lengur en sólarhring og er pað áhyggjuefni. Dánarhlutfall var hærra hjá peim sem biðu lengur en sólarhring, pó ekki tölfræðilega marktækt. Meðallegutími á bæklunardeild er sambærilegur við erlendar rannsóknir en virðist helst ráðast af umönnunarúrræðum utan sjúkrahússins, sem gæti leitt til annaðhvort óparflega stuttrar eða langrar sjúkrahússdvalar en hvort tveggja gæti haft neikvæðar afleiðingar. Dánarhlutfall peirra sem mjaðmarbrotna er sambærilegt við erlendar rannsóknir við 30 daga en í hærri mörkum við eitt ár og mun hærri en gerist í sama aldurspýði á Íslandi. Marktækt færri bjuggu á eigin heimili eftir að hafa brotnað en fyrir brot og purftu vistun á hjúkrunarheimili með tilheyrandi óhagræði fyrir sjúklinga og kostnaði fyrir samfélagið. Mjaðmarbrot hafa pví alvarlegar afleiðingar fyrir einstaklinginn, auka verulega á dánartíðni og draga úr sjálfbjargargetu peirra sem lifa af. Mestur ávinningur væri að forða slíku broti í upphafi en sjúklingar með mjaðmarbrot purfa vel skipulagða pjónustu og nána samvinnu margra fagaðila til draga úr peim fylgikvillum sem peim geta fylgt.

\section{Pakkir}

Pessi rannsókn hlaut styrki frá Sjóði Sigríðar Lárusdóttur og Vísindasjóði Landspítala.

ENGLISH SUMMARY

\section{Treatment and outcome of patients with hip fracture}

Magnusson $\mathrm{KA}^{1}$, Gunnarsson $\mathrm{B}^{2,3}$, Sigurdsson $\mathrm{GH}^{1,4}$, Mogensen $\mathrm{B}^{4,5}$, Olafsson $\mathrm{Y}^{6}$, Karason $\mathrm{S}^{1,4}$

Introduction: Hip fractures are common amongst the elderly, often with serious consequences and increased mortality. The aim of this study was to describe treatment and outcome of patients with hip fractures. Material and methods: Retrospective study on all hip fracture patients $\geq 60$ years of age operated at Landspitali University Hospital in the year 2011.

Results: The study group was made up of 255 patients (mean age $82 \pm$ 8 years, women $65 \%$ ). Mean delay to operation was $22 \pm 14$ hours. Mean length of hospital stay for those living at a nursing home before hip fracture was $4 \pm 2$ days but if they had lived at home $14 \pm 10$ days $(p<0.001)$. Before the fracture $68 \%$ of the patients lived at home but $54 \%$ at the end of follow-up $(p<0.001)$. Mortality one year after hip fracture was $27 \%$ and on average eightfold compared to the general population $\geq 60$ years. A multivariate analysis showed that age, time from fracture to arrival at hospital, ASA-classification and living in a nursing home before fracture were linked to an increased risk of death.

Conclusion: The mean delay to surgery was within recommended guidelines, but one- third waited longer than 24 hours. Resources outside hospital seemed to decide hospital length of stay. Mortality of hip fracture patients was manifold compared to the general population of the same age and within higher range compared to other countries. Significantly fewer lived in their own home after the fracture. Hip fractures cause serious debilitation and are demanding for society. 


\section{Heimildir}

1. Cummings SR, LJ. Melton, Epidemiology and outcomes of osteoporotic fractures. Lancet 2002; 359: 1761-7.

2. Beer $\mathrm{C}$, Giles E. Hip fracture--challenges in prevention and management. Aust Fam Physician 2005; 34: 673-6.

3. Diamantopoulos AP, Hoff M, Skoir IM, Hochberg M, Haugeberg G. Short- and long-term mortality in male and females with fragility hip fracture in Norway. A population-based study. Clin Interv Aging 2013; 8: 817-23.

4. Daugaard $\mathrm{CL}$, Jørgensen HL, Riis $\mathrm{T}$, Lauritzen JB, Duus $\mathrm{BR}$, van der Mark S. Is mortality after hip fracture associated with surgical delay or admission during weekends and public holidays? A retrospective study of 38,020 patients. Acta Orthop 2012; 83: 609-13.

5. Egerod I, Rud K, Specht K, Jensen PS, Trangbaek A Rønfelt I, et al. Room for improvement in the treatment of hip fractures in Denmark. Dan Med Bull 2010; 57: A4199.

6. Williams N, Hardy BM, Tarrant S, Enninghorst N, Attia J, Oldmeadow $\mathrm{C}$, et al. Changes in hip fracture incidence, mortality and length of stay over the last decade in an Australian major trauma centre. Arch Osteoporos 2013; 8 ; 150.

7. Omsland TK, Holvik K, Meyer HE, Center JR, Emaus N, Tell GS, et al. Hip fractures in Norway 1999-2008: time trends in total incidence and second hip fracture rates: a NOREPOS study. Eur J Epidemiol 2012; 27: 807-14.

8. Looker AC, Orwoll ES, Johnston CC Jr, Lindsay RL, Wahner HW, Dunn WL, et al. Prevalence of low femoral bone density in older U.S. adults from NHANES III. J Bone Miner Res 1997; 12: 1761-8.

9. Litwic A, Edwards M, Cooper C, Dennison E. Geographic differences in fractures among women. Womens Health (Lond Engl) 2012; 8: 673-84.

10. Chesser TJ, Handley R, Swift C. New NICE guideline to improve outcomes for hip fracture patients. Injury 2011; 42: 727-9.

11. Bhandari M, Devereaux PJ, Tornetta P 3rd, Swiontkowski MF, Berry DI, Haidukewych G, et al. Operative management of displaced femoral neck fractures in elderly patients. An international survey. J Bone Joint Surg Am 2005; 87: 2122-30.

12. Johnson B, Stevenson J, Chamma R, Patel A, Rhee SJ, Lever $\mathrm{C}$, et al. Short-term follow-up of pertrochanteric fractures treated using the proximal femoral locking plate. J Orthop Trauma 2014; 28: 283-7.
13. Simunovic N, Devereaux PJ, Sprague S, Guyatt GH, Schemitsch E, Debeer J, et al. Effect of early surgery afte hip fracture on mortality and complications: systematic review and meta-analysis. CMAJ 2010; 182: 1609-16.

14. Novack V, Jotkowitz A, Etzion O, Porath A. Does delay in surgery after hip fracture lead to worse outcomes? A multicenter survey. Int J Qual Health Care 2007; 19: 170-6.

15. Majumdar SR, Beaupre LA, Johnston DW, Dick DA Cinats JG, Jiang HX. Lack of association between mortality and timing of surgical fixation in elderly patients with hip fracture: results of a retrospective population-based cohort study. Med Care 2006; 44: 552-9.

16. Bergeron E, Lavoie A, Moore L, Bamvita JM, Ratte $\mathrm{S}$, Gravel C, et al. Is the delay to surgery for isolated hip fracture predictive of outcome in efficient systems? J Trauma 2006; 60: 753-7.

17. Orosz GM, Magaziner J, Hannan EL, Morrison RS, Koval $\mathrm{K}$, Gilbert M, et al. Association of timing of surgery for hip fracture and patient outcomes. JAMA 2004; 291: 1738-43.

18. Neuman MD, Rosenbaum PR, Ludwig JM, Zubizarreta JR, Silber JH. Anesthesia technique, mortality, and length of stay after hip fracture surgery. JAMA 2014; 311: 2508-17.

19. Fields AC, Dieterich JD, Buterbaugh K, Moucha CS. Shortterm complications in hip fracture surgery using spinal versus general anaesthesia. Injury 2015; 46: 719-23.

20. Macfie D, Zadeh RA, Andrews M, Crowson J, Macfie J. Perioperative multimodal optimisation in patient undergoing surgery for fractured neck of femur. Surgeon 2012; 10: 90-4.

21. Brauer CA, Coca-Perraillon M, Cutler DM, Rosen AB. Incidence and mortality of hip fractures in the United States. JAMA 2009; 302: 1573-9.

22. Mundi S, Pindiprolu B, Simunovic N, Bhandari M. Simila mortality rates in hip fracture patients over the past 31 years. Acta Orthop 2014; 85: 54-9.

23. Wang $C B$, Lin $C F$, Liang WM, Cheng $C F$, Chang YJ, Wu $\mathrm{HC}$, et al. Excess mortality after hip fracture among the elderly in Taiwan: a nationwide population-based cohort study. Bone 2013; 56: 147-53.

24. Lund CA, Møller AM, Wetterslev J, Lundstrøm LH. Organizational factors and long-term mortality after hip fracture surgery. A cohort study of 6143 consecutive patients undergoing hip fracture surgery. PLoS One 2014; 9: e99308.
25. American society of anesthesiologists: new classification of physical status. Anesthesiology 1963; 24: 111.

26. Johannesdottir F, Aspelund T, Siggeirsdottir K, Jonsson BY, Mogensen B, Sigurdsson S, et al. Mid-thigh cortical bone structural parameters, muscle mass and strength, and association with lower limb fractures in older men and women (AGES-Reykjavik Study). Calcif Tissue Int 2012; 90: 354-64.

27. Keyak JH, Sigurdsson S, Karlsdottir G, Oskarsdottir D, Sigmarsdottir A, Zhao S, et al. Male-female differences in the association between incident hip fracture and proximal femoral strength: a finite element analysis study. Bone 2011; 48: 1239-45.

28. Siggeirsdottir K, Aspelund T, Jonsson BY, Mogensen B, Gudmundsson EF, Gudnason V, et al. Epidemiology of fractures in Iceland and secular trends in major osteoporotic fractures 1989-2008. Osteoporos Int 2014; 25: 211-9.

29. Socialstyrelsen. Hälso- och sjukvård jämförelser mellan landsting. 2014: 31.

30. Bjorgul K, Reikeras O. Incidence of hip fracture in southeastern Norway: a study of 1,730 cervical and trochanteric fractures. Int Orthop 2007; 31: 665-9.

31. Luger TJ, Kammerlander C, Gosch $M$, Luger MF, Kammerlander-Knauer U, Roth T, et al. Neuroaxial versus general anaesthesia in geriatric patients for hip fracture surgery: does it matter? Osteoporos Int 2010; 21 (Suppl 4): S555-72.

32. Deakin DE, Wenn RT, Moran CG. Factors influencing discharge location following hip fracture. Injury 2008; 39 : 213-8.

33. Kates SL, Behrend C, Mendelson DA, Cram P, Friedman SM. Hospital readmission after hip fracture. Arch Orthop Trauma Surg 2015; 135: 329-37. 